\title{
SEMIOTIKA TANDA VERBAL DAN VISUAL PADA IKLAN KAMPANYE PENCEGAHAN PENYEBARAN COVID-19
}

\author{
I Gusti Ayu Vina Widiadnya Putri \\ Universitas Mahasaraswati Denpasar \\ vina.ayu422@gmail.com
}

\begin{abstract}
ABSTRAK
Penelitian ini dilakukan untuk mengetahui jenis tanda dan makna di balik rangkaian tanda yang muncul dalam iklan, sehingga dapat diketahui apakah iklan telah menggunakan tanda yang dapat mengubah pandangan masyarakat atau tidak. Data diambil dari iklan Layanan Masyarakat tentang kempanye pencegahan Penyebaran Covid-19. Data dalam bentuk brosur, gambar, poster, papan iklan, dan iklan unduhan dari situs web digunakan dalam penelitian ini. Metode analisis yang digunakan adalah semiotika komunikasi verbal dan visual. Data yang dikumpulkan dianalisis secara kualitatif berdasarkan teori dari Barthes (1967). Dalam tanda-tanda visual, data dianalisis berdasarkan teori yang diajukan oleh Wierzbicka (1996) untuk menganalisis tentang warna yang muncul dalam tanda yang disajikan. Berdasarkan analisis data menunjukkan bahwa terdapat tiga temuan yang menjadi hasil dari penelitian ini yaitu pertama; Pertama, tanda verbal yang dimunculkan dalam setiap iklan, mengandung makna konotasi dan denotasi. Kedua, Tanda visual yang dimunculkan menunjukkan beberapa gambar yang memiliki berbagai makna sesuai dengan konteks yang melatar belakangi iklan tersebut bahkan melalui iklan yang tidak mengandung tanda verbal dapat memberikan pesan yang bermakna kepada pembaca. Ketiga, tanda verbal dan tanda visual selain dapat mendukung dan memaknai satu sama lain, kedua tanda ini dapat berdiri sendiri dan menunjukkan makna tersendiri dari pesan yang ingin disampaikan kepada pembaca.
\end{abstract}

Kata kunci: semiotika; tanda verbal; tanda visual

\begin{abstract}
This research was conducted to determine the types of signs and the meaning behind the series of signs that appear in advertisements, so it can be seen whether the advertisement has used signs that can change people's views or not. The data was taken from the Public Service advertisement about the campaign to prevent Covid-19 spread. Data in the form of brochures, images, posters, billboards, and download advertisements from the website were used in this research. The analytical method used was verbal and visual communication semiotics. The collected data were analyzed qualitatively based on the theory from Barthes (1967). In visual signs, the data were analyzed based on the theory proposed by Wierzbicka (1996) to analyze the colors that appear in the signs presented. Based on the analysis of the data, there are three findings which are the results of this study: first, verbal signs that appear in every advertisement, contain connotation and denotation meaning. Second, the visual signs that appear show a number of images that have various meanings in accordance with the context behind the advertisement, even through ads that do not contain verbal signs can provide meaningful messages to the reader. Third, verbal signs and visual signs in addition to being able to support and interpret each other, these two signs can stand alone and show their own meaning of the message to be conveyed to the reader.
\end{abstract}

Keywords: semiotic; verbal sign; visual sign

\section{PENDAHULUAN}

Keberadaan iklan tidak terlepas dari unsur verbal dan visual. Menurut Liliweri, aktivitas komunikasi adalah penciptaan interaksi perorangan dengan menggunakan tanda yang tegas (Alo Liliweri, 1991:20). Komunikasi juga berarti pembagian unsur-unsur perilaku, atau cara hidup dengan eksistensi seperangkat 
ketentuan dan pemakaian tanda-tanda yang telah disepakati. Komunikasi yang dilakukan dapat berupa tulis dan lisan. Salah satu bentuk komunikasi tulis yang sering digunakan di masyarakat adalah Periklanan. Periklanan didefinisikan sebagai pesan yang menawarkan produk yang ditujukan untuk komunitas melalui media (Kasali, 1992: 9). Produk yang dimaksud tidak hanya dalam bidang komersial namun juga dapat berupa tujuan yang ingin disampaikan oleh penulis kepada para pembacanya. Iklan dirancang dan ditampilkan semenarik mungkin tanpa menghilangkan pesan penting yang terkandung dalam iklan. Bahasa iklan harus persuasif dan menarik untuk memengaruhi para pembaca. Bahasa yang digunakan adalah bahasa pendek, jelas, solid yang efektif dan dapat mempengaruhi pembaca. Agar lebih menarik, iklan juga didukung oleh penggunaan warna, ilustrasi, dan logo. Terdapat dua jenis iklan yaitu iklan komersil dan iklan non-komersil yang sering juga disebut sebagai ILM (Iklan Layanan Masyarakat). Sementara itu, iklan layanan masyarakat dapat dipahami sebagai sebuah pengumuman atau pemberitahuan yang tidak dipungut bayaran untuk memajukan sebuah program, aktivitas atau layanan pemerintah pusat maupun pemerintah daerah, atau aktivitas sosial untuk layanan organisasi nonprofit dan pemberitahuan lain yang dianggap bermanfaat untuk masyarakat (J.L. \& and C.W. Lamb, 1986: 428).

Dalam iklan layanan masyarakat disajikan pesan sosial yang dimaksudkan untuk membangkitkan kepedulian masyarakat terhadap sejumlah masalah yang harus mereka hadapi (Kasali, 1992: 201). Iklan kampanye yang mulai diserukan di masyarakat saat ini ditengah wabah covid yang telah menjadi pandemic glogal adalah Iklan Kampanye Pencegahan Penyebaran Covid-19. Pemerintah dan kalangan masyarakat banyak menyerukan kampanye pencegahan penyebaran covid-19 sejak kemunculannya di Indonesia pada pertengahan bulan Februari tahun 2020 lalu. Menurut Ad Council, kriteria yang digunakan untuk menentukan kampanye iklan layanan masyarakat adalah: nonkomersial, tidak bersifat keagamaan, nonpolitik, berwawasan nasional, diperuntukkan bagi seluruh lapisan masyarakat, diajukan oleh organisasi yang telah diakui, dapat diiklankan, mempunyai dampak dan kepentingan tinggi sehingga patut memperoleh dukungan media lokal ataupun nasional (Kasali, 1992: 202). Kampanye ini menjadi hal yang sederhana yang dapat dilakukan oleh pemerintah pusat dan seluruh kalangan masyarakat dalam pencegahan penyebaran Covid-19. Kampanye pencegahan penyebaran covid-19 dilaksanakan bertujuan untuk memberikan pemahaman kepada pembaca untuk tetap waspada dan tetap melakukan protocol kesehatan yang dihimbau oleh pemerintah. Gaya bahasa yang digunakan menjadi hal penting dalam pembuatan iklan. Menurut Keraf, gaya bahasa dapat dibatasi sebagai cara mengungkapkan pikiran melalui bahasa secara khas yang memperlihatkan jiwa dan kepribadian penulis (pemakai bahasa) (Keraf, 1991). Pendek kata, penggunaan gaya bahasa tertentu dapat mengubah serta menimbulkan konotasi tertentu. Gaya bahasa merupakan bentuk retorik, yaitu penggunaan kata-kata dalam berbicara dan menulis untuk meyakinkan mempengaruhi penyimak dan pembaca (Tarigan, 1995). Karena tidak semua masyarakat memiliki pengetahuan yang sama tentang wabah penyakit ini, sehingga diperlukan iklan dengan mengaplikasikan pesan verbal dan visual dengan menggunakan gaya bahasa, gambar, simbul yang baik untuk dikampanyekan di media masa sebagai penyebaran infomrmasi terkait wabah Covid19 yang sudah menjadi pandemic global. Keberadaan iklan tidak dapat dipisahkan dari tanda-tanda verbal dan visual yang mendukung iklan kampanye tersebut menjadi bermakna dan memberikan ilustrasi yang baik bagi pembaca.

Beberapa penelitian tentang Semiotik yang menganalisis tentang tanda verbal dan visual telah dilakukan oleh beberapa peneliti, diantaranya Pratiwi menganalisis tentang makna verbal dan visual pada iklah minuman di televisi (Pratiwi \& Warami, 2015). Iklan yang dipilih adalah iklan komersil yang menemunkan bahwa tanda verbal dan visual yang digunakan dalam iklan minuman di televisi sebagian besar mengandung makna konotative. Penelitian lainnya tentang analisis tanda adalah dari Tinarbuko menganalisis tentang Semiotika Tanda Verbal dan Tanda Visual Iklan Layanan Masyarakat (Tinarbuko, 2016). Metode analisis semiotika komunikasi 
visual juga dimanfaatkan sebagai metode analisis data verbal dan data visual dalam penelitian ini, sebagai salah satu metode pembacaan Iklan Layanan Masyarakat (ILM) akibat adanya kecenderungan untuk memandang berbagai hal, seperti seni, budaya, sosial, desain komunikasi visual, dan ILM sebagai fenomena bahasa dan tanda. Penelitian dari Suciyanto juga mengungkapkan tentang analisis semitotik pada poster Greenpeace Campaign Posters in Climate Change Series (Suciyanto, 2016). Penelitian ini menemukan bahwa hal penting dalam menggambarkan makna poster adalah dari kemampuan penafsiran penelitian. Jadi interpretasi makna poster tergantung pada pengetahuan, pengalaman, latar belakang dan budaya.

Iklan kampanye pencegahan Covid-19 merupakan iklan tidak komersil yang akan mempertimbangkan penggunaan tanda verbal dan nonverbal, sehingga, para pembaca dapat memahami arti tanda yang akan ditransmisikan oleh pengiklan. Bentuk iklan layanan masyarakat dengan topik kampanye pencegahan penyebaran Covid-19 yang berbeda dengan jenis iklan layanan masyarakat lainnya membuat hal ini sangat menarik untuk diteliti. Gambar, warna, tanda, kata-kata dan frasa yang terkandung dalam iklan termasuk dalam tanda-tanda verbal dan non-verbal yang memerlukan penelitian lebih dalam agar lebih memahami tentang makna yang terkandung dalam iklan kampanye ini. Penelitian ini dilakukan untuk mengetahui jenis tanda dan makna di balik rangkaian tanda yang muncul dalam iklan, sehingga dapat diketahui apakah iklan telah menggunakan tanda yang dapat mengubah pandangan masyarakat atau tidak.

\section{METODE}

Data diambil dari iklan Layanan Masyarakat tentang kempanye pencegahan Penyebaran Covid-19. Data dalam bentuk brosur, gambar, poster, papan iklan, dan iklan unduhan dari situs web digunakan dalam penelitian ini. Iklan-iklan ini dipilih sebagai sumber data karena mengandung tanda-tanda verbal dan visual yang menarik untuk dianalisis. Ada kecenderungan bahwa penggunaan tanda pada jenis iklan ini berbeda dengan iklan layanan masyarakat dengan kampanye lainnya. Data dikumpulkan dengan teknik observasi dan mencatat, dan data juga dikumpulkan melalui penelitian lapangan dan penelitian online. Metode analisis yang digunakan adalah semiotika komunikasi verbal dan visual yang pada dasarnya beroperasi pada dua jenjang analisis. Pertama, analisis tanda secara individual, mencakup: tanda, kode, dan makna tanda. Kedua, analisis tanda yang membentuk teks. Sedangkan teks menurut Yasraf Amir Piliang dipahami sebagai kombinasi tanda-tanda (Yasraf Amir Piliang, 1998). Dengan demikian, karya desain komunikasi visual salah satunya berbentuk ILM juga dapat dilihat sebagai sebuah teks. Data yang dikumpulkan dianalisis secara kualitatif berdasarkan teori dari Barthes. Dalam tanda-tanda visual, data dianalisis berdasarkan teori yang diajukan oleh Wierzbicka untuk menganalisis tentang warna yang muncul dalam tanda yang disajikan (Wierzbicka, 1996).

\section{PEMBAHASAN}

Data dianalisis dengan Semiotika tanda verbal dan visual. Analisis didasarkan pada teori dari Barthes (1967). Menurut Barthes tanda adalah senyawa penanda dan tanda (signifier and signified) (Barthes, 1974). Bagi Barthes, penanda selalu merupakan substansi material yang dapat berupa suara, benda, gambar (Barthes, 1974: 47). Sementara itu yang ditandakan adalah representasi mental dari suatu hal. Signified terkait dengan 'sesuatu' yang dihubungkan oleh orang yang menggunakan sign Barthes (Barthes, 1974: 43). Tanda-tanda dibedakan menjadi dua yaitu tanda verbal dan visual. Tanda verbal adalah bagian dalam iklan yang dapat dianalisis melalui teks atau dalam bentuk tulisan. Sebuah iklan biasanya terdiri dari teks dalam bentuk nama atau slogan iklan, informasi tentang sesuatu, kalimat persuasi atau bentuk teks lainnya. Sedangkan tanda visual atau non verbal yaitu jenis tanda dalam iklan yang digunakan untuk mendukung bagian verbal untuk membuat iklan terlihat lebih menarik. Bagian non-verbal ini bisa dalam bentuk warna, musik atau suara, animasi atau gambar. Dalam menafsirkan tanda itu, terjadi dua tingkat interpretasi. Tingkat pertama adalah primer (denotasi) dan tingkat sekunder (konotasi). Denotasi terjadi ketika suatu tanda didefinisikan secara harfiah, jelas atau berdasarkan pada definisi yang masuk akal 
(Chandler, 2007: 137). Denotasi adalah tanda paling umum yang ditemukan di masyarakat karena berkaitan dengan definisi kamus. Barthes dalam Piliang (1999) menjelaskan bahwa denotatif adalah hubungan antara penanda dan makna yang menghasilkan makna langsung dan pasti (Barthes in Yasraf Amir Piliang, 1998). Sedangkan konotasi, menurut Barthes dalam Krampen (1987: 80), konotasi adalah "nada" dari suatu teks atau cara yang telah didekorasi (Barthes in Krampen, 1987). Konotatif adalah tingkat signifikansi antara penanda dan makna yang menghasilkan makna tidak langsung dan tidak terbatas (Barthes, 1974: 91). Sementara itu, konotasi "digunakan untuk merujuk pada asosiasi sosial-budaya dan 'pribadi' (ideologis, emosional, dll.) (Chandler, 2007: 138) Dari tanda".Analisis warna pada tanda-tanda yang muncul dianalisis dengan theory Wierzbicka (1996). Menurut Wierzbicka, warna bukanlah konsep manusia universal tetapi berkaitan dengan mengamati karena warna hanya dapat didefinisikan melalui pengamatan(Wierzbicka, 1996: 287).

\section{Data 1}

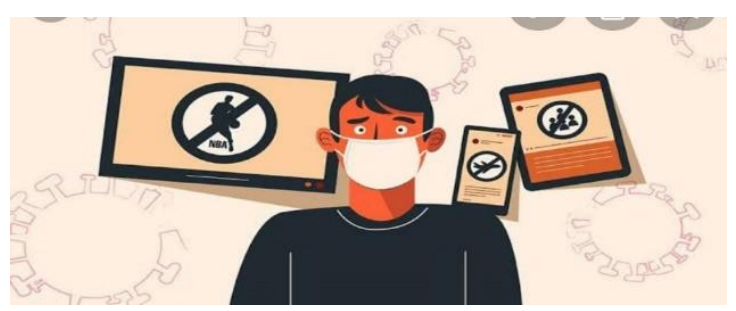

Tabel 1. Tanda Visual

\begin{tabular}{lcc}
\hline Tanda & $\begin{array}{l}\text { Signifier } \\
\text { (penanda) }\end{array}$ & $\begin{array}{l}\text { Signified } \\
\text { (petanda) }\end{array}$ \\
\hline Verbal: & - & - \\
- & & \\
\hline & & \\
\hline
\end{tabular}

Visual:

\begin{tabular}{lll} 
Simbol & Gambar & Untuk \\
seorang laki- & memberikan \\
laki dengan & gambaran \\
menggunakan & tentang \\
masker & sebuah \\
& kecemasan. \\
& Tiga buah & Aktifitas \\
pigura dengan & keseharian \\
masing-maing & yang selalu \\
gambar yang & dilakukan \\
\hline
\end{tabular}

\begin{tabular}{|c|c|c|}
\hline & $\begin{array}{l}\text { berbeda dan } \\
\text { berbentuk } \\
\text { larangan }\end{array}$ & $\begin{array}{l}\text { dan tidak } \\
\text { dapat } \\
\text { dilakukan } \\
\text { saat pandemi } \\
\text { covid-19. }\end{array}$ \\
\hline \multirow[t]{2}{*}{ Background } & $\begin{array}{l}\text { Bakground } \\
\text { dengan } \\
\text { gambar } \\
\text { menyerupai } \\
\text { bentuk virus }\end{array}$ & $\begin{array}{l}\text { Untuk } \\
\text { mendukung } \\
\text { ilustrasi } \\
\text { kecemasan } \\
\text { yang } \\
\text { dirasakan. }\end{array}$ \\
\hline & $\begin{array}{l}\text { Warna latar } \\
\text { belakang } \\
\text { merah gelap }\end{array}$ & $\begin{array}{l}\text { Rasa } \\
\text { nyaman. }\end{array}$ \\
\hline
\end{tabular}

Data satu merupakan gambar ilustrasi yang menarik untuk dianalisis. Poster tersebut tidak memiliki tanda verbal yang mendukungnya, namun tersimpan interpretasi yang menarik dalam tanda visual yang ditunjukan. Menurut Barthes tanda adalah senyawa penanda, penanda selalu merupakan substansi material yang dapat berupa suara, benda, gambar (Barthes, 1974). Sementara itu yang ditandakan adalah representasi mental dari suatu hal. Penanda yang ditunjukkan dalam poster tersebut adalah gambar seorang laki-laki yang sedang menggunakan masker dengan mata yang sayu. Ini dapat menandai bahwa kondisi pandemic covid-19 merupakan kondisi yang sangat serius. Tanda kecemasan sangat tampak terlihat dimata laki-laki itu sebagai penanda yang dapat mengilustrasikan bahwa kecemasan yang terlalu berlebihan merupakan hal yang tidak perlu dilakukan. Penanda masker ditunjukkan dalam gambar tersebut yang menandakan bahwa, pada masa pandemic global covid-19, masker terbukti secara signifikan mengurangi jumlah virus yang terdeteksi dalam partikel yang dilepaskan saat seseorang bernapas dan batuk, sehingga masker merupakan benda yang wajib digunakan oleh seseorang. Tanda yang ditunjukkan di bagian background adalah tiga gambar kegiatan yang biasa dilakukan diluar rumah dan diberikan simbul larangan. Gambar tersebut menandai bahwa seluruh kegiatan diluar rumah tidak dapat dilakukan dimasa pandemic covid-19 ini. Untuk mendukung simbul yang ditampilkan dalam poster tersebut, pencipta poster menggunakan kesan nyaman dengan warna ungu muda di bagian background poster. Pesan 
yang ingin disampaikan oleh penulis dalam poster kampanye ini adalah, masyarakat sebaiknya menjaga diri dengan tidak melakukan aktifitas diluar rumah dan mengurangi rasa kecemasan yang berlebihan. Dengan tidak melakukan kegiatan diluar rumah, masyarakat sudah dapat melakukan aksi pemutusan rantai penyebaran covid-19. Satusatunya kegiatan yang sangat bermakna bagi seluruh masyarakat di masa pandemic covid-19 ini adalah menghilangkan rasa kecemasan yang berlebih. Tetap tinggal dirumah, nikmati seluruh aktifitas di dalam rumah bersama keluarga dan tidak merasakan kecemasan yang berlebihan adalah pesan inti yang ingin disampaikan oleh si pencipta poster kepada pembaca. Tanda yang ditunjukkan dalam poster tesebut mengandung makna konotasi. Konotatif adalah tingkat signifikansi antara penanda dan makna yang menghasilkan makna tidak langsung dan tidak terbatas (Barthes, 1974: 91).

Data 2

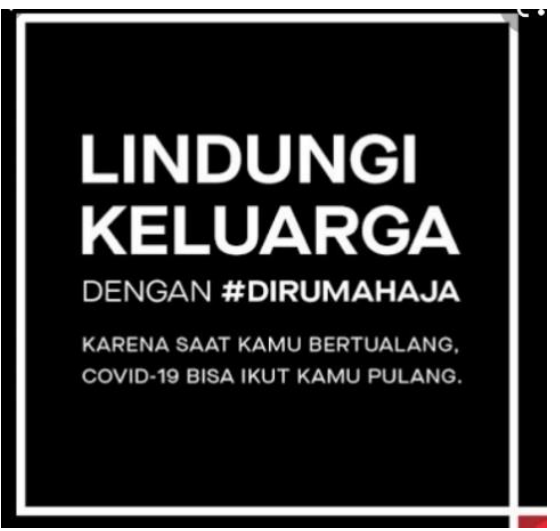

Tabel 2. Tanda Verbal dan Visual

\begin{tabular}{lll}
\hline Tanda & $\begin{array}{l}\text { Signifier } \\
\text { (Penanda) }\end{array}$ & $\begin{array}{l}\text { Signified } \\
\text { (Petanda) }\end{array}$ \\
\hline $\begin{array}{l}\text { Verbal: } \\
\text { Teks atau } \\
\text { kalimat }\end{array}$ & LINDUNGI & Untuk \\
& KELUARGA & $\begin{array}{l}\text { membujuk } \\
\text { pembaca tetap } \\
\text { melindungi } \\
\text { keluarga. }\end{array}$ \\
\hline & & Memberikan \\
& DENGAN & $\begin{array}{l}\text { himbauan } \\
\text { kepada } \\
\text { \#DIRUMAaca untuk } \\
\text { tetap tinggal } \\
\text { dirumah dan } \\
\text { melakukan }\end{array}$
\end{tabular}

\begin{tabular}{|c|c|c|}
\hline & $\begin{array}{l}\text { KERENA } \\
\text { SAAT KAMU } \\
\text { BERTUALAN } \\
\text { G COVID-19 } \\
\text { BISA IKUT } \\
\text { KAMU } \\
\text { PULANG. }\end{array}$ & $\begin{array}{l}\text { aksi dirumah } \\
\text { saja. } \\
\text { Mengingatkan } \\
\text { pembaca } \\
\text { tentang bahaya } \\
\text { covid-19. }\end{array}$ \\
\hline $\begin{array}{l}\text { Visual: } \\
\text { Background }\end{array}$ & Huruf Kapital & $\begin{array}{l}\text { Untuk } \\
\text { menginterpreta } \\
\text { sikan } \\
\text { kekhawatiran. } \\
\text { Untuk menarik } \\
\text { perhatian } \\
\text { pembaca. }\end{array}$ \\
\hline
\end{tabular}

Gambar poster diatas menunjukkan dominasi tanda verbal. Tanda verbal pertama yang ditunjukkan dalam poster tersebut adalah: LINDUNGI KELUARGA. Penanda ini merupakan jenis phrasa aktif atau kalimat bujukan. Kalimat tersebut bertujuan untuk membujuk seseorang untuk melakukan sesuatu. Petanda yang disampaikan dalam kalimat tersebut untuk membujuk seseorang tetap melindungi keluarga mereka ditengah pandemic covid-19 yang sedang terjadi. Tanda verbal kedua adalah: DENGAN \#DIRUMAHAJA. Penanda ini bertujuan untuk memberikan himbauan kepada pembaca untuk tetap tinggal dirumah. Dalam kata dirumah aja, penulis menambakan hashtag (\#) yang merupakan tanda di sosial media (tweeter) dengan makna mencari dukungan untuk melakukan aksi secara bersama-sama. Penulis ingin menyerukan dan medapatkan dukungan dari pembaca untuk melakukan aksi dirumah ajah. Penanda ketiga yaitu: KERENA SAAT KAMU BERTUALANG COVID-19 BISA IKUT KAMU PULANG. Kalimat tersebut merupakan kalimat konfirmasi yang dituliskan penulis untuk mengingatkan pembaca bahwa covid-19 dapat saja membahayakan keluarga dan orang-orang terdekat. Makna pesan verbal dari data diatas merupakan makna denotasi. Denotasi terjadi ketika suatu tanda didefinisikan secara harfiah, jelas atau berdasarkan pada definisi yang masuk akal (Chandler, 2007: 137). Selain penanda verbal, terdapat penanda visual yang mendukung pesan 
dari poster tersebut. Penanda visual yang dimunculkan dalam poster tersebut adalah Jenis huruf capital yang digunakan untuk dalam mendukung tanda verbal. Jenis huruf yang dipilih oleh pencipta poster adalah jenis huruf kapital yang bertujuan ingin menarik perhatian pembaca tentang pesan verbal yang ingin disampaikan. Warna background yang digunakan adalah warna hitam. Warna hitam dipilih untuk menginterpretasikan kekhawatiran yang tengah terjadi, selain itu warna hitam dapat memberikan kesan jelas untuk pesan verbal yang ditampilkan. Sehingga pembaca dapat dengan mudah memahami maksud dan tujuan penulis melalui poster tersebut. Pesan verbal yang ingin disampaikan penulis kepada pembaca adalah himbauan, bujukan dan ajakan dari penulis untuk melakukan suatu aksi ditengah pandemic covid-19.

\section{Data 3}

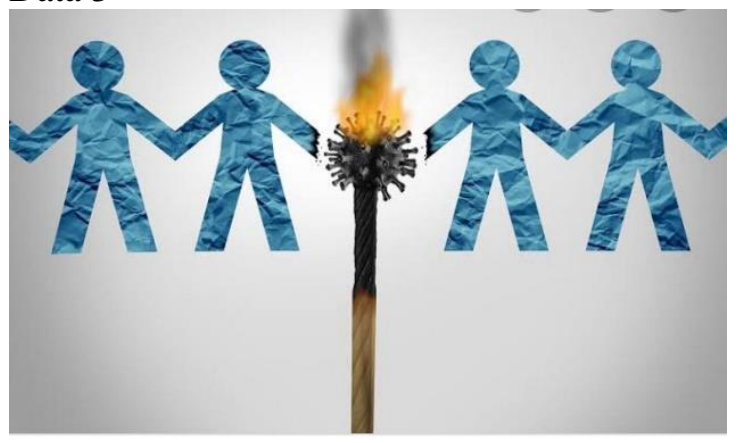

Tabel 3. Tanda Visual

\begin{tabular}{|c|c|c|}
\hline Tanda & $\begin{array}{l}\text { Signifier } \\
\text { (penanda) }\end{array}$ & $\begin{array}{l}\text { Signified } \\
\text { (petanda) }\end{array}$ \\
\hline $\begin{array}{l}\text { Verbal : } \\
-\end{array}$ & - & - \\
\hline \multicolumn{3}{|l|}{ Visual: } \\
\hline Simbol & $\begin{array}{l}\text { Ilustrasi } \\
\text { manusia } \\
\text { bergandengan } \\
\text { tangan } \\
\text { Korek api } \\
\text { menyala }\end{array}$ & $\begin{array}{l}\text { Menunjukkan } \\
\text { ilustrasi cara } \\
\text { penyebaran } \\
\text { virus covid-19. } \\
\text { Memberikan } \\
\text { informasi } \\
\text { kepada } \\
\text { pembaca } \\
\text { Langkah } \\
\text { effective dalam } \\
\text { memutus } \\
\text { penyebaran }\end{array}$ \\
\hline
\end{tabular}

covid-19.

\begin{tabular}{ll} 
Background Putih & $\begin{array}{l}\text { Lingkungan } \\
\text { yang bersih } \\
\text { tanpa covid-19. }\end{array}$ \\
\hline
\end{tabular}

Poster diatas menunjukkan tanda visual dengan tidak didukung oleh penanda verbal. Penanda visual yang ditunjukkan adalah: Manusia dengan berbahan kertas yang mengilustrasikan interaksi manusia yang sebenarnya, korek api menyala untuk mengilustrasikan keganasan virus covid-19. Pencipta poster ingin menunjukkan pesan kepada pembaca dengan menggunakan tanda visual secara keseluruhan. Tanda visual pertama yang ditunjukkan yaitu symbol manusia yang sedang bergandengan tangan. Symbol ini menandai bahwa awalnya terjadi hubungan interaksi masyarakat yang baik antara satu sama lain. Namun, ketika pandemic covid-19 ini berlangsung, kebersamaan seperti itu tidak dapat dilakukan seperti sedia kala. Tanda visual kedua adalah: Korek api, Ilustrasi manusia bergandengan tangan lalu dipisahkan oleh korek api yang sedang menyala menandai bahwa penyebaran virus yang begitu cepat menyebar dan dapat menginfeksi orang lain sehingga harus segera dilakukan aksi pemutusan rantai virus. Pemilihan korek api sebagai penanda visual dengan alasan bahwa korek memiliki senyawa api yang mudah terbakar jika menyentuh permukaan benda. Simbul manusia dalam poster tersebut juga digambarkan bagai sehelai kertas yang jika terkena api akan sangat mudah terbakar. Signified terkait dengan 'sesuatu' yang dihubungkan oleh orang yang menggunakan sign (Barthes, 1974). Penanda yang dipilih dalam poster tersebut dapat dikorelasikan dengan pesan yang ingin disampaikan oleh pencipta poster, bahwa langkah effective untuk memutus mata rantai penyebaran covid-19 yaitu dengan menjaga jarak. Dengan tetap menjaga jarak, api yang diilustrasikan sebagai virus tidak dapat menyebar kesiapapun. Api akan mati dengan sendirinya jika tidak membakar apapun disekitarnya. Begitu juga dengan sifat virus covid-19 ini, virus tidak akan menginfeksi siapapun jika tidak berada didalam inangnya. Sehingga menjaga jarak dan tidak melakukan kontak dengan siapapun adalah 
langkah yang paling effective dalam memutus rantai penyebaran virus covid-19. Keseluruhan simbul tersebut didukung dengan background berwarna putih cerah yang menandai tentang kesehatan dan keceriaan. Pemutusan rantai virus covid-19 dengan menjaga jarak, akan membuat lingkungan menjadi sehat kembali. Pesan inti yang ingin disampaikan oleh si pembuat poster adalah mengajak pembaca untuk bersama-sama memutus rantai penyebaran virus dengan aksi menjaga jarak satu sama lain. Tanda yang ditunjukkan dalam poster tesebut mengandung makna konotasi. Konotatif adalah tingkat signifikansi antara penanda dan makna yang menghasilkan makna tidak langsung dan tidak terbatas (Barthes, 1974: 91).

Data 4

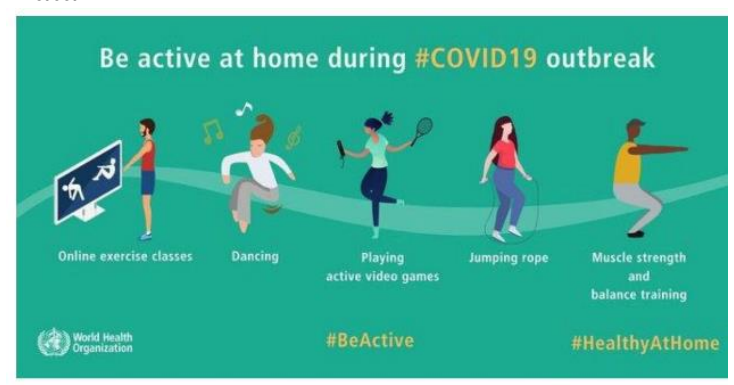

Tabel 4. Tanda Verbal dan Visual

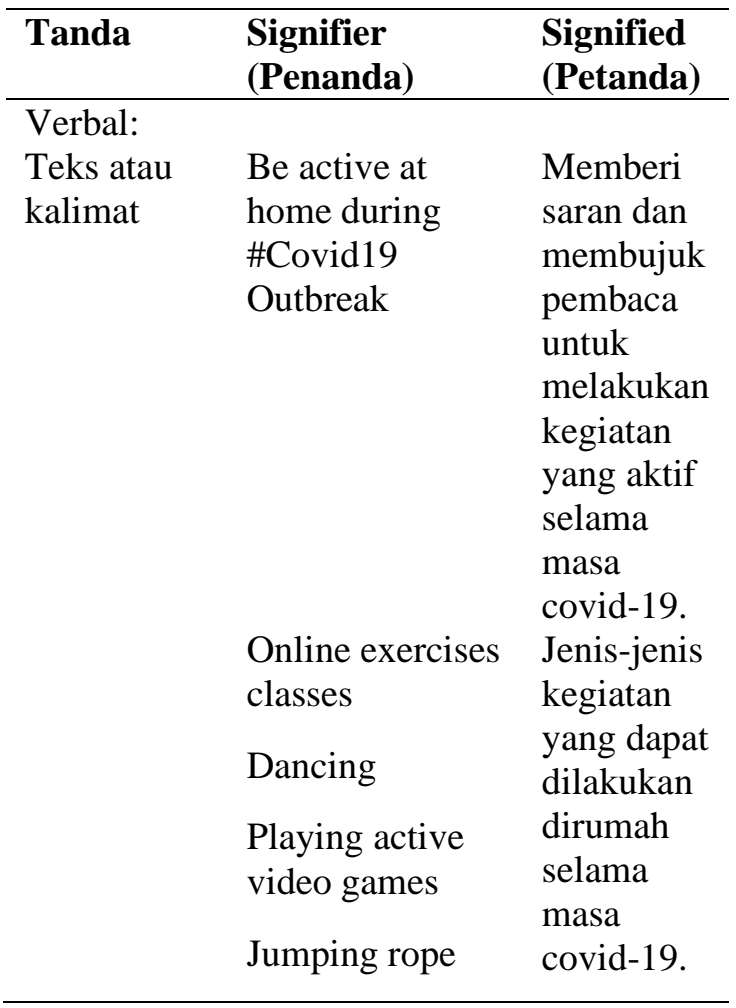

Muscle strength

and balance

training

\begin{tabular}{lll}
\hline Visual: & & \\
Gambar & Simbul Orang & Menunjuk \\
& yang sedang & kan \\
& melakukan & kepada \\
aktifitas. & pembaca \\
& & tentang \\
& & jenis-jenis \\
aktifitas \\
& & yang \\
& & dilakukan \\
& Jenis media & Menunjuk \\
& yang digunakan & kan dan \\
& untuk & memberi \\
& melakukan & contoh \\
& aktifitas (TV, & seluruh \\
& tali,handphone) & kegiatan \\
& & dapat \\
& & dilakukan \\
& & didalam \\
& & rumah. \\
& & Kesejukan \\
Background & Warna hijau & kesehatan \\
& & \\
& &
\end{tabular}

Poster diatas menunjukkan tanda verbal dan visual yang saling berhubungan. Menurut teori dari Barthes (1967) tanda-tanda dibedakan menjadi dua yaitu tanda verbal dan visual. Tanda verbal adalah bagian dalam iklan yang dapat dianalisis melalui teks atau dalam bentuk tulisan. Sedangkan tanda visual atau non verbal yaitu jenis tanda dalam iklan yang digunakan untuk mendukung bagian verbal untuk membuat iklan terlihat lebih menarik. Bagian non-verbal ini bisa dalam bentuk warna, musik atau suara, animasi atau gambar. Tanda visual yang ditunjukkan mampu mendukung tanda verbal yang ingin disampaikan. Tanda verbal yang digunakan berupa text. Menurut Yasraf Amir Piliang text dipahami sebagai kombinasi tanda-tanda. Dengan demikian, karya desain komunikasi visual yang salah satunya berbentuk dalam iklan juga dapat dilihat sebagai sebuah teks (Yasraf Amir Piliang, 1998: 88). Tanda verbal yang pertama adalah kalimat: Be active at home during Covid19 Outbreak yang bermakna aktif dirumah selama penyebaran covid-19. Jenis kalimat yang digunakan adalah kalimat aktif dengan tujuan 
memberikan saran kepada pembaca untuk melakukan suatu tindakan. Kegiatan yang disarankan oleh si pembuat poster, ditunjukkan dalam tanda verbal kedua yaitu : Online exercises classes, Dancing, Playing active video, games, Jumping rope, Muscle strength and balance training yang bermakna latihan di kelas online, menari, menghidupkan video, bermain game, dan lompat tali. Seluruh kegiatan yang disarankan si pembuat poster kepada pembaca ditunjukkan dengan tanda verbal dan didukung dengan tanda visual yang mengilustrasikan kegiatan-kegiatan tersebut. Tanda verbal ketiga yaitu: \#BeActive \#HealtyAtHome yang bermakna aktif dan sehat dirumah. Tujuan dari tanda verbal yang ditunjukkan adalah memberikan himbauan kepada pembaca untuk melakukan kegiatan sehat dirumah. Tanda verbal tersebut didukung dengan menggunakan hashtag (\#) untuk menegaskan bahwa si pembuat poster ingin dengan serius menyerukan dan mengajak seluruh pembaca melakukan kegiatan sehat dirumah. Makna yang terkandung dalam pesan verbal poster diatas adalah makna denotative. Denotasi adalah tanda paling umum yang ditemukan di masyarakat karena berkaitan dengan definisi kamus. Barthes dalam Piliang (1999) menjelaskan bahwa denotatif adalah hubungan antara penanda dan makna yang menghasilkan makna langsung dan pasti

Selain tanda verbal, tanda visual juga dimunculkan dalam poster tersebut untuk mendukung pesan verbal yang ingin disampaikan kepada pembaca. Tanda visual yang pertama adalah: Simbul Orang yang sedang melakukan aktifitas. Simbul orang yang sedang melakukan aktifitas didalam rumah, selain ditunjukkan untuk mendukung tanda verbal yang dimunculkan, tanda ini juga ditunjukkan untuk memberikan informasi dan memberikan contoh kepada pembaca tentang jenis-jenis aktifitas yang dapat dilakukan dirumah selama covid-19. Tanda visual kedua yaitu: Jenis media yang digunakan untuk melakukan aktifitas (TV, tali, handphone). Tanda visual ini digunakan untuk menunjukkan kepada pembaca dan memberi jenis media yang dapat digunakan dalam melakukan kegiatan sehat didalam rumah. Warna latar belakang poster diatas menggunakan warna hijau yang mengandung makna kesejukan dan kesehatan.
Si pembuat poster ingin memperjelas makna dibalik pembuatan poster tersebut dengan menampilkan warna hijau yang merupakan simbul dari kesehatan dan kesejukan. Warna hijau tersebut ditampilkan untuk mendukung seluruh makna dari tanda verbal dan visual dari poster tersebut. Jenis huruf dengan warna putih diberikan untuk memperjelas pesan dan makna tanda verbal dan tanda visual yang diumnuclkan. Pesan inti yang ingin disampaikan dalam poster tersebut adalah mengajak seluruh pembaca untuk melakukan kegiatan sehat dirumah selama masa covid-19 berlangsung.

\section{SIMPULAN}

Setelah dilakukan analisis yang mendalam terhadap iklan layanan masyarakat jenis poster ketika kampanye penyebaran covid-19, maka dapat disimpulkan bahwa:

Pertama, tanda verbal yang dimunculkan dalam setiap iklan, mengandung makna denotasi. Makna denotasi adalah Denotasi terjadi ketika suatu tanda didefinisikan secara harfiah, jelas atau berdasarkan pada definisi yang masuk akal (Chandler, 2007: 137). Makna yang terkandung dalam iklan layanan masyarakat jenis poster ketika kampanye penyebaran covid-19, meningterprestasikan himbauan dan ajakan kepada pembaca untuk melakukan aksi atau kegiatan yang bermakna. Tanda verbal yang digunakan pada dasarnya untuk memberikan saran kepada pembaca tentang bahaya covid-19 dan mengajak pembaca melakukan aksi untuk meminimalis penyebaran covid-19 yang sejalan dengan tujuan pemerintah.

Kedua, Tanda visual yang dimunculkan menunjukkan beberapa gambar yang memiliki berbagai makna sesuai dengan konteks yang melatar belakangi iklan tersebut. Beberapa iklan tidak mengandung tanda verbal, namun dapat memberikan pesan yang bermakna kepada pembaca dengan ilustrasi yang sempurna. Tanda visual selain untuk mendukung tanda verbal yang diikutinya, tanda visual dapat pula berdiri sendiri dengan memiliki makna sendiri tanpa didukung oleh tanda verbal yang mengikutinya.

Ketiga, tanda verbal dan tanda visual selain dapat mendukung dan memaknai satu sama lain, kedua tanda ini dapat berdiri sendiri dan 
menunjukkan makna tersendiri dari pesan yang ingin disampaikan kepada pembaca dengan didukung ilustrasi yang sempurna.

\section{DAFTAR PUSTAKA}

Alo Liliweri. (1991). Memahami Peran Komunikasi Massa dalam Masyarakat. PT Citra Aditya Bakti.

Barthes, R. (1974). 'S/Z', terjemahan dari $S / Z$ oleh Richard Miller. Hill and Wang.d.

Chandler, D. (2007). The Basic Semiotics. Routledge.

J.L., C., \& and C.W. Lamb. (1986). Marketing Government and Social Service. John Willey and Son.

Kasali, R. (1992). Manajemen Periklanan: Konsep dan Aplikasinya Di Indonesia. Pustaka Utama Grafiti.

Keraf, G. (1991). Diksi dan Gaya Bahasa. PT Gramedia Pustaka Utama.

Krampen, M. (1987). Classics of Semiotics: Ferdinand de Saussure and the Development of Semiology. Plenum Press.
Pratiwi, D. P. E., \& Warami, H. (2015). Makna Tanda Verbal dan Non-Verbal pada Iklan Minuman di Televisi. Jurnal Kibas Cendrawasih, 12(1).

Suciyanto, S. . (2016). Semiotic Analysis of Greenpeace Campaign Posters in Climate Change Series. State Islamic University Syarif Hidayatullah.

Tarigan, H. G. (1995). Pengajaran Gaya Bahasa. Angkasa.

Tinarbuko, S. (2016). Semiotika Tanda Verbal dan Visual. Jurnal Panggung, 26(2). https://www.researchgate.net/publication/ 320375806_Semiotika_Tanda_Verbal_da n_Tanda_Visual_Iklan_Layanan_Masyar akat

Wierzbicka, A. (1996). Semantics: primes and universals. Oxford University Press.

Yasraf Amir Piliang. (1998). Sebuah Dunia yang Dilipat, Realitas Kebudayaan menjelang Milenium Ketiga dan Matinya Posmodernisme. Mizan. 